\title{
Konsep Manajemen Trans Batik Solo sebagai Pendukung Sektor Pariwisata di Kota Surakarta
}

\author{
Management Concept of Trans Batik Solo to Support Tourism in \\ Surakarta City
}

\author{
Rizky Arif Nugroho $^{1, a)}$, Eko Budi Santoso ${ }^{2, b)}$ \& Cahyono Susetyo $^{2, c)}$ \\ 1) Perencanaan Wilayah dan Kota, Institut Teknologi Kalimantan, Balikpapan. \\ 2) Perencanaan Wilayah dan kota, Institut Teknologi Sepuluh Nopember, Surabaya.
}

Koresponden : ${ }^{a)}$ arif.rizky@itk.ac.id, ${ }^{b}$ ekobudis@hotmail.com \& ${ }^{c}$ csusetyo@gmail.com

\begin{abstract}
ABSTRAK
Pariwisata sangat erat kaitannya dengan sektor transportasi. Bagi pariwisata, sektor transportasi berfungsi sebagai penyedia akses menuju suatu tempat tujuan. Fungsi utama transportasi sangat erat kaitannya dengan aksesibilitas. Dengan kata lain, sektor transportasi memudahkan penggunanya mengunjungi daerah tertentu, misalnya objek wisata. Penelitian ini bertujuan untuk merumuskan konsep manajemen Batik Solo Trans sebagai pendukung sektor pariwisata di Kota Surakarta. Dalam merumuskan konsep agar Batik Solo Trans dapat mendukung sektor pariwisata di Kota Surakarta, digunakan triangulasi antara hasil kajian yang dikombinasikan dengan kebijakan lokal terkait serta referensi literatur yang telah ada sebelumnya. Konsep yang diperoleh yakni (1) disediakan informasi yang cukup mengenai Batik Solo Trans, (2) disediakan kursi prioritas bagi perempuan atau ladies priority section, (3) menggunakan armada yang berkapasitas penumpang cukup besar atau menambah jumlah unit armadanya, (4) penerapan Park and Ride, (5) Batik Solo Trans ditingkatkan kinerjanya, (6) membentuk branding Batik Solo Trans untuk mendukung sektor pariwisata di Kota Surakarta, (7) dilakukan penambahan trayek agar seluruh objek wisata di Kota Surakarta dapat dijangkau oleh Batik Solo Trans, dan (8) menggunakan metode Bus Priority untuk mengurangi kemacetan.
\end{abstract}

Kata Kunci : manajemen aset fasilitas, fasilitas transportasi pariwisata, pariwisata, Konsep, Trans Batik Solo

\section{PENDAHULUAN}

Manajemen aset merupakan proses pengorganisasian, perencanaan dan pengawasan terhadap Pembangunan sektor pariwisata di Kota Surakarta belum optimal akibat integrasi jaringan transportasi dan pariwisata yang belum terpadu (Rudy, 2018). Akibatnya, potensi wisata yang dimiliki Kota Surakarta tidak dapat dikembangkan secara maksimal akibat adanya permasalahan sektor transportasi. Menurut Badan Promosi Pariwisata Surakarta (2012), kemacetan yang timbul dapat menghambat laju aktivitas pariwisata di Kota Surakarta. Bahkan menurut penelitian yang dilakukan oleh Teteki (2010), menunjukkan bahwa kemacetan menghambat pengembangan potensi pariwisata di Kota Surakarta. Kondisi lalu lintas di sekitar Pasar Gede belum teratur dan ketersediaan lahan parkir yang minim menyebabkan terjadinya kemacetan. Kemacetan tersebut akan menghambat perjalanan wisata para pengunjung dan wisatawan sehingga wisatawan tidak merasa tenang dan nyaman ketika melakukan perjalanan wisata. Selain itu, menurut Teteki (2010), lokasi Pasar Gede yang berada pada jalur lintasan transportasi umum merupakan salah satu faktor yang dapat 
mendukung Pasar Gede sebagai salah satu objek wisata karena kemudahan aksesibilitasnya. Salah satu upaya untuk mengurangi kemacetan yaitu dengan memanfaatkan sektor transportasi umum. Kota Surakarta sendiri memiliki program untuk mengatasi kemacetan, salah satunya adalah melalui penggunaan Batik Solo Trans sebagai moda transportasi umum bagi masyarakat (Herman 2014). Oleh karena itu upaya yang dapat dilakukan untuk mengembangkan potensi pariwisata di Kota Surakarta adalah dengan meningkatkan kinerja sektor transportasi umum khususnya Batik Solo Trans. Melalui dukungan Batik Solo Trans terhadap sektor pariwisata maka potensi pariwisata di Kota Surakarta dapat berkembang dengan maksimal.

Sektor pariwisata merupakan sektor yang sedang berkembang pesat di Surakarta. Pengembangan pariwisata tidak bisa dilepaskan dari hubungan antara sektor pariwisata dengan sektor transportasi. Kota Surakarta memiliki potensi wisata budaya dan kuliner namun dalam pelaksanaannya masih terkendala masalah kemacetan yang akan menghambat laju aktivitas pariwisata di Kota Surakarta. Pada bidang transportasi umum sendiri, Kota Surakarta telah memiliki Batik Solo Trans namun tingkat pemanfaatannya sendiri masih rendah.

Dengan demikian maka Tujuan penulisan Makalah ini adalah untuk merumuskan konsep manajemen Batik Solo Trans sebagai pendukung sektor pariwisata di Kota Surakarta.

\section{METODA PENELITIAN}

Woodruff (dalam Sinurat 2011), mendefinisikan konsep sebagai suatu gagasan/ide yang relatif sempurna dan bermakna, suatu pengertian tentang suatu objek, produk subjektif yang berasal dari cara seseorang membuat pengertian terhadap objek-objek atau benda-benda melalui pengalamannya (setelah melakukan persepsi terhadap objek/benda). Sedangkan manajemen merupakan ilmu dan seni yang mengatur proses pemanfaatan sumber daya manusia dan sumber lainnya secara efektif dan efisien untuk mencapai suatu tujuan tertentu (Hasibuan 2006). Selain kedua pengertian tersebut, perlu dipahami terlebih dahulu definisi dari fasilitas itu sendiri. Fasilitas merupakan hal-hal yang diperlukan dalam hidup, Fasilitas harus dikelola dengan baik, agar fasilitas bisa selalu berfungsi dengan baik secara ekonmis, efisien dan efektif (Soemitro \& Suprayitno 2018). Moda Batik Solo Trans merupakan fasilitas bagi masyarakat untuk bergerak dari satu tempat ke tempat lainnya.

Dalam penelitian ini berarti konsep yang dimaksud adalah tentang gagasan mengenai proses pemanfaatan transportasi umum untuk mencapai tujuan tertentu yaitu mendukung pariwisata di Kota Surakarta. Teknik yang digunakan dalam merumuskan konsep adalah teknik analisis kualitatif berupa triangulasi dimana peneliti mempertimbangkan hasil dari sasaran-sasaran yang telah dicapai kemudian dikombinasikan dengan kebijakan terkait serta referensi literatur yang telah ada sebelumnya untuk kemudian dirumuskan menjadi sebuah konsep manajemen transportasi umum yang mendukung potensi pariwisata di Kota Surakarta. Dalam merumuskan konsep juga akan dijabarkan perbandingan sederhana mengenai pengaruh penggunaan transportasi umum terhadap volume kendaraan di Kota Surakarta yang menjadi penyebab kemacetan lalu lintas.

\section{ANALISIS PENELITIAN}

Dalam merumuskan Konsep Manajemen Batik Solo Trans Sebagai Pendukung Sektor Pariwisata di Kota Surakarta dilakukan dengan teknik triangulasi. Analisa teknik triangulasi adalah teknik analisa dengan menggunakan tiga sumber data sebagai dasar pertimbangan dalam merumuskan konsep. Dalam penelitian ini, dasar pertimbangan yang digunakan adalah :

Hasil analisis peneliti mengenai karakteristik wisatawan, kinerja Batik Solo Trans, dan aksesibilitas Batik Solo Trans terhadap objek daya tarik wisata di Kota Surakarta. 
1. Kebijakan pengembangan lokal di Kota Surakarta.

2. Referensi/best practice dalam manajemen transportasi umum.

Dengan melakukan pertimbangan atas ketiga dasar tersebut, maka dapat dirumuskan konsep manajemen Batik Solo Trans sebagai pendukung sektor pariwisata di Kota Surakarta. Dalam merumuskan Konsep Manajemen Batik Solo Trans Sebagai Pendukung Sektor Pariwisata di Kota Surakarta dilakukan dengan teknik triangulasi. Analisa teknik triangulasi adalah teknik analisa dengan menggunakan tiga sumber data sebagai dasar pertimbangan dalam merumuskan konsep.

Pertama, hasil analisis mengenai karakteristik wisatawan, kinerja Batik Solo Trans, dan aksesibilitas Batik Solo Trans terhadap objek daya tarik wisata di Kota Surakarta. Dalam merumuskan konsep mengenai manajemen Batik Solo Trans, perlu diketahui karakteristik wisatawan yang berkunjung ke Kota Surakarta. Hal ini perlu diketahui karena wisatawan inilah yang akan menaiki Batik Solo Trans dalam melakukan kegiatan wisata di Kota Surakarta. Wisatawan yang berkunjung ke Kota Surakarta dilihat dari karakteristik geografis, demografis, fisiologis, dan pola perjalanan wisata yang dilakukan adalah sedikit didominasi oleh kaum perempuan berusia muda yaitu antara 15-24 tahun dengan status belum kawin. Mayoritas merupakan pelajar/mahasiswa/karyawan dengan tingkat pendidikan paling banyak adalah SMA. Para wisatawan tersebut hanya tinggal di Kota Surakarta selama $<12$ jam saja, walaupun ada sebagian yang memutuskan menginap atau tinggal $>24$ jam. Hal ini mempengaruhi alokasi anggaran yang mereka siapkan sebelum berkunjung ke Kota Surakarta dimana mereka kebanyakan hanya menyiapkan untuk biaya perjalanan dan transportasi selama di Kota Surakarta saja. Meskipun demikian, ada pula yang mempersiapkan alokasi untuk penginapan, khususnya bagi wisatawan yang memutuskan untuk tinggal di Kota Surakarta $>24$ jam. Pola perjalanan yang dilakukan banyak dipengaruhi oleh karakteristik demografis dan fisiologis yang telah disebutkan sebelumnya. Kebanyakan wisatawan berkunjung ke Kota Surakarta dengan rombongan dan tidak menggunakan biro perjalanan. Mereka berkunjung ke Kota Surakarta dalam rangka liburan. Selain itu mereka memilih menggunakan moda transportasi sepeda motor karena dirasa lebih efisien, bebas macet, santai, dan murah.

Kedua, Kebijakan pengembangan lokal di Kota Surakarta. Konsep yang akan disusun harus disesuaikan dengan kebijakan pengembangan lokal yang ada di Kota Surakarta, baik transportasi maupun wisata. Menurut kebijakan pengembangan transportasi lokal di Kota Surakarta, dilakukan peningkatan kinerja pelayanan pada kapasitas transportasi di Kota Surakarta untuk jaringan jalan dengan pengembangan manajemen lalu lintas maupun dengan meminimalkan hambatan samping. Peningkatan kapasitas ini juga dilakukan pada sistem sarana angkutan dengan mengarahkan pada sistem Sarana Angkutan Umum Massal (SAUM). Sedangkan menurut kebijakan pengembangan wisata lokal di Kota Surakarta, dilakukan penempatan Kota Surakarta sebagai kota yang punya mandat menguatkan nilai-nilai budaya Jawa sebagai kekayaan bangsa. Terdapat pula isu strategis mengenai kepariwisataan di Kota Surakarta seperti penguatan karakter budaya kawasan dengan cara mengintegrasikan pembangunan karakter fisik lingkungan dengan pengembangan ekonomi wilayah dan pengembangan pariwisata budaya berbasis lokalitas.

Ketiga, referensi/best practice dalam manajemen transportasi umum. Dalam merumuskan konsep tentang manajemen Batik Solo Trans perlu diberikan referensi sebagai acuan dalam mengembangkan konsep tersebut. Referensi dikumpulkan dari berbagai sumber terkait dengan penyampaian informasi, pembentukan branding, mengenali pengguna dan peningkatan kinerja dalam manajemen transportasi umum.

Adapun hasil dari penyusunan konsep manajemen transportasi umum sebagai pendukung sektor pariwisata di Kota Surakarta adalah sebagai berikut : 
Penyediaan informasi yang cukup mengenai Batik Solo Trans.

1. Penyediaan kursi prioritas bagi perempuan atau ladies priority section.

2. Penyediaan jaminan kapasitas Batik Solo Trans cukup untuk menampung wisatawan rombongan

3. Penerapan Park and Ride.

4. Peningkatan kinerja Batik Solo Trans.

5. Pembentukan citra Batik Solo Trans sebagai angkutan pendukung pariwisata.

6. Penambahan trayek Batik Solo Trans yang menjangkau seluruh ODTW di Kota Surabaya

7. Penggunaan metode Bus Priority.

Dengan adanya peningkatan kualitas pelayanan dari Batik Solo Trans, maka orangorang akan berpindah menggunakan Batik Solo Trans. Kondisi ini akan mendorong berkurangnya jumlah volume kendaraan pada ruas jalan dan pada akhirnya akan mampu mengurangi timbulnya titik kemacetan. Dengan demikian maka potensi pariwisata di Kota Surakarta dapat dimaksimalkan. 
Tabel 1. Analisa Triangulasi Konsep Manajemen Batik Solo Trans Sebagai Pendukung Sektor Pariwisata

\begin{tabular}{|c|c|c|c|}
\hline Hasil Analisis & Kebijakan Pengembangan Lokal & Referensi & Konsep Manajemen \\
\hline $\begin{array}{l}\text { - Karakteristik wisatawan di } \\
\text { Surakarta } \\
\text { Karakteristik }\end{array}$ & 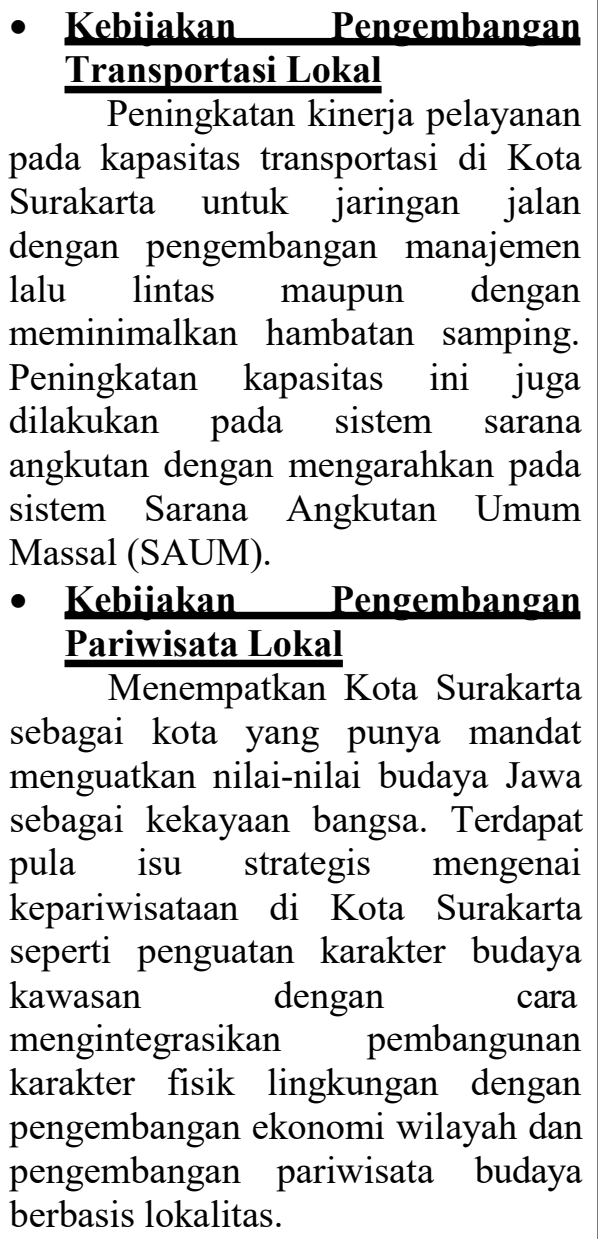 & 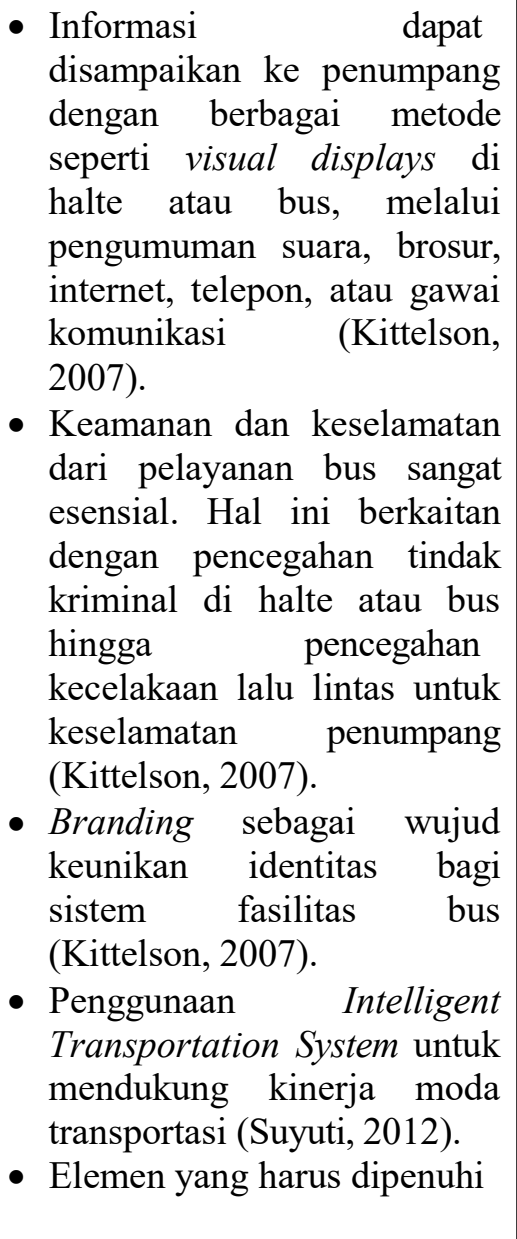 & $\begin{array}{l}\text { 1. Penyediaan } \\
\text { informasi } \\
\text { yang cukup } \\
\text { mengenai Batik } \\
\text { Solo Trans. } \\
\text { 2. Penyediaan kursi } \\
\text { prioritas bagi } \\
\text { perempuan atau } \\
\text { ladies priority } \\
\text { section. } \\
\text { 3. Penyediaan } \\
\text { jaminan kapasitas } \\
\text { Batik Solo Trans } \\
\text { cukup untuk } \\
\text { menampung } \\
\text { wisatawan } \\
\text { rombongan. } \\
\text { 4. Penerapan } \\
\text { Park and Ride. } \\
\text { 5. Peningkatan } \\
\text { kinerja Batik } \\
\text { Solo Trans. } \\
\text { 6embentukan } \\
\text { citra Batik Solo } \\
\text { Tran sebagai } \\
\text { angkutan } \\
\text { pendukung } \\
\text { pariwisata. }\end{array}$ \\
\hline
\end{tabular}


Kebanyakan wisatawan berkunjung ke Kota Surakarta dengan rombongan dan tidak menggunakan biro perjalanan. Mereka berkunjung ke Kota Surakarta dalam rangka liburan. Selain itu mereka memilih menggunakan moda transportasi sepeda motor karena dirasa lebih efisien, bebas macet, santai, dan murah. Namun demikian, mayoritas tertarik untuk mencoba menggunakan Batik Solo Trans, adapun yang tidak tertarik beralasan bahwa informasi dan kejelasan mengenai Batik Solo Trans sulit untuk dicari

\section{- Kineria Batik Solo Trans di Kota} Surakarta

Dalam meningkatkan kinerjanya, terdapat beberapa hal yang perlu dijadikan prioritas untuk diperbaiki. Hal-hal tersebut antara lain Batik Solo Trans perlu dilengkapi oleh lampu isyarat tanda bahaya dan adanya petugas keamanan. Perlu dipastikan juga agar kepadatan jalan yang dilalui oleh Batik Solo Trans relatif lancar, lalu Batik Solo Trans harus seminimal mungkin terlibat dalam kecelakaan lalu lintas, dan memiliki tarif yang sesuai dengan kemampuan masyarakat.

\section{- Aksesibilitas Batik Solo Trans terhadap} objek dava tarik wisata

Aksesibilitas Batik Solo Trans terhadap objek daya tarik wisata di Kota Surakarta

antara lain diketahui jika objek wisata unggulan menurut wisatawan adalah Keraton Kasunanan Surakarta. Jika dilihat aksesibilitasnya, maka objek wisata Keraton
Dalam memberikan informasi

adalah kejelasan dimana

informasi dapat diperoleh,

tersedia kontak untuk

informasi lanjutan,

konsistensi informasi,

melatih staf untuk dapat

menyampaikan informasi

dengan benar, konten

informasi harus terbaru

(UNWTO, 2016).

- Salah satu metode yang digunakan adalah metode bus priority, yaitu mengurangi konflik-konflik kendaraan di sepanjang lintasan rute (Tahir, 2005).

- Dalam menyediakan pelayanan terhadap wisatawan, perlu diketahui karakteristik mereka

(Mantero \& Freitas 2013).

- Generasi muda saat ini cenderung mengurangi aktivitas mengendarai sendiri kendaraannya dan beralih menggunakan moda transportasi alternatif. Hal ini akan cenderung terjadi

- untuk beberapa waktu ke depan (Davis et al, 2012).

- Park and Ride berfungsi sebagai feeder bagi 


\begin{tabular}{|c|c|}
\hline $\begin{array}{l}\text { Kasunanan Surakarta, Pasar Klewer, dan } \\
\text { Taman Balekambang memiliki aksesibilitas } \\
\text { rendah karena memiliki jarak lebih dari } 500 \\
\text { meter dari halte yang ada. Lain halnya dengan } \\
\text { aksesibilitas kebutuhan akomodasi penginapan } \\
\text { bagi wisatawan yang termasuk dalam } \\
\text { aksesibilitas tinggi karena trayek Batik Solo } \\
\text { Trans sudah menjangkau area sekitar Jalan } \\
\text { Slamet Riyadi dimana banyak terdapat } \\
\text { akomodasi penginapan. } \\
\text { Aksesibilitas antar halte termasuk cukup } \\
\text { tinggi karena jarak antar halte berkisar antara } \\
\text { 200-500 meter, walaupun ada beberapa titik } \\
\text { halte tertentu yang berjarak di luar tersebut. } \\
\text { Untuk jarak terpendek adalah 167 meter } \\
\text { sedangkan jarak terpanjang mencapai } 2 \\
\text { kilometer. Untuk tingkatan pelayanan ruas } \\
\text { jalan di sekitar titik rawan kemacetan } \\
\text { mayoritas masih rendah, yaitu tingkat C dan D } \\
\text { sehingga aksesibilitasnya pun berkurang. } \\
\text { Terakhir, berdasarkan perhitungan } \\
\text { matematis sederhana, diketahui bahwa } \\
\text { kebutuhan armada untuk Koridor } 1 \text { dan } \\
\text { Koridor } 2 \text { adalah } 24 \text { armada sehingga eksisting } \\
\text { saat ini untuk Koridor } 1 \text { sudah mencukupi. } \\
\text { Sedangkan untuk Koridor } 2 \text { dibutuhkan } 3 \\
\text { armada lagi. }\end{array}$ & $\begin{array}{l}\text { transportasi umum utama } \\
\text { dimana penggunanya akan } \\
\text { memarkirkan kendaraannya di } \\
\text { sebuah lokasi tertentu dan } \\
\text { beralih menggunakan moda } \\
\text { transportasi umum (Meek et } \\
\text { al, 2008). }\end{array}$ \\
\hline
\end{tabular}




\section{KESIMPULAN}

Konsep manajemen transportasi umum dalam mendukung sektor pariwisata di Kota Surakarta dirumuskan sebagai upaya dalam memajukan sektor pariwisata di Kota Surakarta. Sektor pariwisata di Kota Surakarta mengalami kendala akibat masalah kemacetan lalu-lintas. Dengan mendorong wisatawan menggunakan sarana transportasi umum di Kota Surakarta, yaitu Batik Solo Trans, maka diharapkan kemacetan yang ada di Kota Surakarta tidak terlalu dirasakan oleh wisatawan dan ke depannya dapat mengurangi potensi timbulnya kemacetan tersebut. Dalam merumuskan Konsep Manajemen Batik Solo Trans Sebagai Pendukung Sektor Pariwisata di Kota Surakarta dilakukan dengan teknik triangulasi. Analisa teknik triangulasi adalah teknik analisa dengan menggunakan tiga sumber data sebagai dasar pertimbangan dalam merumuskan konsep.

Adapun hasil dari penyusunan konsep manajemen transportasi umum sebagai pendukung sektor pariwisata di Kota Surakarta adalah sebagai berikut :

1. Penyediaan informasi yang cukup mengenai Batik Solo Trans.

2. Penyediaan kursi prioritas bagi perempuan atau ladies priority section.

3. Penyediaan jaminan kapasitas Batik Solo Trans cukup untuk menampung wisatawan rombongan

4. Penerapan Park and Ride.

5. Peningkatan kinerja Batik Solo Trans.

6. Pembentukan citra Batik Solo Tran sebagai angkutan pendukung pariwisata.

7. Penambahan trayek Batik Solo Trans yang menjangkau seluruh ODTW di Kota Surakarta.

8. Penggunaan metode Bus Priority.

Dengan adanya peningkatan kualitas pelayanan dari Batik Solo Trans, maka orang orang akan berpindah menggunakan Batik Solo Trans. Kondisi ini akan mendorong berkurangnya jumlah volume kendaraan pada ruas jalan dan pada akhirnya akan mampu mengurangi timbulnya titik kemacetan. Dengan demikian maka potensi pariwisata di Kota Surakarta dapat dimaksimalkan.

\section{DAFTAR PUSTAKA}

Badan Promosi Pariwisata Surakarta. (2012). Pelaku Wisata Desak Pemkot Solo Harus Punya Jalur Alternatif. Diakses pada 20 April 2016, dari http://www.joglosemar.com

Davis, B., Dutzik, T., \& Baxandall, P. (2012). Transportation and The New Generation. Why Young People Are Driving Less and What It Means for Transportation Policy. Frontier Group.

Hasibuan, M. SP. (2006). Manajemen Sumber Daya Manusia. Edisi Revisi, Cetakan Kedelapan. PT. Bumi Aksara. Jakarta.

Herman, Y. (2014). 5 Tahun ke Depan, Solo Diprediksi Macet Total. Diakses pada 16 Mei 2017, dari http://www.solopos.com.

Kittelson \& Associates (2007). Bus Rapid Transit Practitioner's Guide (Vol. 118). Transportation Research Board. Herbert S. Levinson Transportation Consultants, DMJM+ HARRIS., Transit Cooperative Research Program, United States. Federal Transit Administration \& Transit Development Corporation.

Mantero, C. \& Freitas, A. (2013). Tourism and Public Transport : Best practice toolkit in Madeira, CIVITAS Forum, Brest. 
Meek, S., Ison, S., \& Enoch, M. (2009). "Stakeholder Perspectives on The Current and Future Roles of UK Bus-Based Park and Ride". Journal of Transport Geography, 17(6), 468475 .

Rudy, F. X. (2018). Wali Kota Solo : Sektor Wisata Belum Tergarap Optimal. Diakses pada 25 April 2019, dari http://www.tribunsolo.com

Sinurat, H. (2011). "Analisis Kontrastif Kata Keterangan Waktu Dalam Bahasa Indonesia dan Bahasa Mandarin".

Soemitro, R.A.A. \& Suprayitno, H. (2018). "Pemikiran Awal tentang Konsep Dasar Manajemen Aset Fasilitas". Jurnal Manajemen Aset Infrastruktur \& Fasilitas, Vol. 2, Suplemen 1, Juni 2018, hal. : 1-13.

Suyuti, R. (2012). ""Implementasi Intelligent Transportation System (ITS) Untuk Mengatasi Kemacetan Lalu Lintas di DKI Jakarta”. Konstruksia, 3(2).

Tahir, A. (2012). "Angkutan Massal Sebagai Alternatif Mengatasi Persoalan Kemacetan Lalulintas Kota Surabaya". SMARTek, 3(3).

Teteki, N. W. (2010). "Potensi Pasar Gede Sebagai Obyek dan Daya Tarik Wisata Budaya dan Kuliner di Kota Solo".

UNWTO (2016). UNWTO Recommendations on Accessible Information in Touris., United Nation World Tourism Orrganization. Madrid. 
(e)ISSN 2615-1847 (p)ISSN 2615-1839

Jurnal Manajemen Aset Infrastruktur \& Fasilitas - Vol. 3, No. 1, Maret 2019 